\title{
Methylobacterium iners sp. nov. and Methylobacterium aerolatum sp. nov., isolated from air samples in Korea
}

\author{
Hang-Yeon Weon, ${ }^{1}$ Byung-Yong Kim, ${ }^{2}$ Jae-Ho Joa, ${ }^{3}$ Jung-A Son, ${ }^{1}$ \\ Myung-Hee Song, ${ }^{2}$ Soon-Wo Kwon, ${ }^{2}$ Seung-Joo Go ${ }^{2}$ \\ and Sang-Hong Yoon ${ }^{2}$

\begin{abstract}
${ }^{1}$ Applied Microbiology Division, National Institute of Agricultural Science and Technology, Rural Development Administration (RDA), Suwon 441-707, Republic of Korea
\end{abstract}

Correspondence

Soon-Wo Kwon swkwon@rda.go.kr
${ }^{2}$ Korean Agricultural Culture Collection (KACC), Microbial Genetics Division, National Institute of Agricultural Biotechnology, RDA, Suwon 441-707, Republic of Korea

${ }^{3}$ National Institute of Subtropical Agriculture, RDA, Jeju 690-150, Republic of Korea

Two bacterial strains isolated from air samples, $5317 \mathrm{~S}-33^{\top}$ and $5413 \mathrm{~S}-11^{\top}$, were characterized by determining their phenotypic characteristics, cellular fatty acid profiles and phylogenetic positions based on 16S rRNA gene sequence analysis. 16S rRNA gene sequence analysis showed that these isolates belonged to the genus Methylobacterium. Strain $5317 \mathrm{~S}-33^{\top}$ was most closely related to Methylobacterium adhaesivum AR27 ${ }^{\top}$ ( $97.9 \%$ sequence similarity). Strain 5413S- $11^{\top}$ was most closely related to Methylobacterium fujisawaense DSM 5686 ${ }^{\top}$ (97.3\% sequence similarity), Methylobacterium oryzae $\mathrm{CBMB}^{\top} \mathrm{O}^{\top}$ ( $97.1 \%$ similarity) and Methylobacterium radiotolerans JCM $2831^{\top}$ ( $97.0 \%$ similarity). Cells of both strains were strictly aerobic, Gram-negative, motile and rod-shaped. The major fatty acid was $\mathrm{C}_{18: 1} \omega 7 \mathrm{c}$. The $\mathrm{G}+\mathrm{C}$ contents of the genomic DNA were 68.0 mol\% for strain $5317 \mathrm{~S}-33^{\top}$ and $73.2 \mathrm{~mol} \%$ for strain $5413 S-11^{\top}$. According to DNA-DNA hybridization data, strain $5317 \mathrm{~S}-33^{\top}$ showed a level of DNA-DNA relatedness of $33 \%$ with $M$. adhaesivum DSM $17169^{\top}$, and strain $5413 S-11^{\top}$ showed low levels of DNA-DNA relatedness $(<35 \%)$ with $M$. fujisawaense DSM $5686^{\top}, M$. oryzae CBMB20 ${ }^{\top}$ and $M$. radiotolerans DSM $1819^{\top}$. On the basis of this polyphasic analysis, it was concluded that strains $5317 \mathrm{~S}-33^{\top}$ and $5413 \mathrm{~S}-11^{\top}$ represent two novel species within the genus Methylobacterium, for which the names Methylobacterium iners sp. nov. (type strain $5317 \mathrm{~S}-33^{\top}=\mathrm{KACC} 11765^{\top}=\mathrm{DSM} 19015^{\top}$ ) and Methylobacterium aerolatum sp. nov. (type strain $5413 S-11^{\top}=$ KACC $11766^{\top}=$ DSM $19013^{\top}$ ) are proposed.
The genus Methylobacterium was originally proposed by Patt et al. (1976). This genus was characterized as containing strictly aerobic, Gram-negative and pinkpigmented facultatively methylotrophic bacteria (Green, 1992). Members of the genus Methylobacterium have been isolated mainly from soil and water (Corpe \& Rheem, 1989; Lidstrom \& Chistoserdova, 2002).

In the course of study of the bacterial population in air samples, two pink-coloured bacterial strains were isolated. Air samples were collected in the Suwon region, Republic

The GenBank/EMBL/DDBJ accession numbers for the 16S rRNA gene sequences of strains $5317 \mathrm{~S}-33^{\top}$ and $5413 \mathrm{~S}-11^{\top}$ are EF174497 and EF174498, respectively.

Cellular fatty acid compositions of strains $5317 \mathrm{~S}-33^{\top}$ and $5413 \mathrm{~S}-11^{\top}$ and related Methylobacterium species are detailed as supplementary material available with the online version of this paper. of Korea, using an MAS-100 air sampler (single-stage multiple-hole impactor; Merck). The sampler contained Petri dishes with R2A agar (BBL) amended with $0.02 \%$ cycloheximide (Sigma). After sampling, plates were incubated at $28{ }^{\circ} \mathrm{C}$ for 5 days and strains $5317 \mathrm{~S}-33^{\mathrm{T}}$ and 5413S$11^{\mathrm{T}}$ were recovered. Routine cultivation was conducted at $28{ }^{\circ} \mathrm{C}$ with R2A media.

Cell morphology was examined by light microscopy (AXIO; Zeiss). The test for motility was performed on one-tenth-strength R2A broth 2216 (Difco) supplemented with $0.2 \%$ agar. Anaerobic growth was tested by incubating cultures on R2A plates in a GasPak jar (BBL) for 14 days, with aerobically incubated plates as controls. Growth at different temperatures $\left(5-45^{\circ} \mathrm{C}\right)$ and $\mathrm{pH}$ values $(4,5,6,7,8,9$ and 10) was monitored in R2A broth. The requirement for $\mathrm{NaCl}$ was tested in $\mathrm{R} 2 \mathrm{~A}$ broth supplemented with $0,2,3,5$ and $7 \%(w / v) ~ N a C l$. Gram-staining, 
catalase and oxidase activities and hydrolysis of aesculin, casein, CM-cellulose, DNA, hypoxanthine, tyrosine, Tween 80, starch and xanthine were determined as described by Smibert \& Krieg (1994). For the various physiological tests, API 20NE and API ZYM test strips (bioMérieux) were used according to the manufacturer's instructions. Biolog GN2 plates were used to test activity against 95 carbon substrates. Both strains were strictly aerobic, Gramnegative, motile and rod-shaped. Strain $5317 \mathrm{~S}-33^{\mathrm{T}}$ grew on R2A (Difco) and R2A plus $0.5 \%$ methanol, but did not grow on nutrient agar (NA; Difco), NA plus $0.5 \%$ methanol, trypticase soy agar (Difco) or MacConkey agar (Difco). Strain $5413 \mathrm{~S}-11^{\mathrm{T}}$ grew on R2A (Difco), R2A plus $0.5 \%$ methanol, NA and NA plus $0.5 \%$ methanol, but did not grow on trypticase soy agar or MacConkey agar. Both strains could be differentiated clearly from their close relatives by several phenotypic characteristics such as nitrate reduction, urease, gelatin hydrolysis, substrate assimilation and enzyme activities (Table 1).

Whole-cell fatty acids were analysed according to the standard protocol of the MIDI/Hewlett-Packard Microbial

Table 1. Differential properties of strains $5317 \mathrm{~S}-33^{\top}$ and $5413 \mathrm{~S}-11^{\top}$ and closely related Methylobacterium species

Strains: $1,5317 \mathrm{~S}-33^{\mathrm{T}} ; 2,5413 \mathrm{~S}-11^{\mathrm{T}} ; 3$, M. adhaesivum DSM $17169^{\mathrm{T}} ; 4$, M. fujisawaense DSM 5686 ${ }^{\mathrm{T}} ; 5$, M. mesophilicum DSM $1708^{\mathrm{T}} ; 6, \mathrm{M}$. oryzae KACC $11585^{\mathrm{T}} ; 7$, M. radiotolerans DSM $1819^{\mathrm{T}}$. According to the API 20NE test strip, all strains are negative for indole production, glucose fermentation, arginine dihydrolase, aesculin hydrolysis and $\beta$ galactosidase. None of the strains assimilate D-mannose, D-mannitol, $\mathrm{N}$-acetylglucosamine, maltose, capric acid or phenylacetic acid. According to the API ZYM test strip, all strains are positive for esterase (C4), esterase lipase (C8), leucine arylamidase and naphtholAS-BI-phosphohydrolase, but negative for lipase (C14), cystine arylamidase, $\alpha$-chymotrypsin, $\alpha$-galactosidase, $\beta$-galactosidase, $\beta$ glucuronidase, $\alpha$-glucosidase, $\beta$-glucosidase, $N$-acetyl- $\beta$-glucosaminidase, $\alpha$-mannosidase and $\alpha$-fucosidase. + , Positive; $(+)$, weakly positive; - , negative.

\begin{tabular}{|lccccccc|}
\hline Characteristic & $\mathbf{1}$ & $\mathbf{2}$ & $\mathbf{3}$ & $\mathbf{4}$ & $\mathbf{5}$ & $\mathbf{6}$ & $\mathbf{7}$ \\
\hline Nitrate reduction & - & - & - & - & - & + & + \\
Urease & - & + & + & - & - & - & - \\
Gelatin hydrolysis & + & - & - & - & - & - & - \\
Assimilation of: & & & & & & & \\
$\quad$ D-Glucose & - & $(+)$ & $(+)$ & - & - & - & + \\
L-Arabinose & - & $(+)$ & $(+)$ & + & + & + & + \\
Potassium gluconate & - & $(+)$ & - & + & + & + & + \\
Adipic acid & - & - & - & + & + & + & + \\
$\quad$ Malic acid & - & + & - & + & + & + & + \\
$\quad$ Trisodium citrate & - & + & + & - & + & - & - \\
Activity of: & & & & & & & \\
$\quad$ Alkaline phosphatase & + & + & + & - & - & - & - \\
$\quad$ Valine arylamidase & - & - & - & - & - & + & - \\
Trypsin & + & - & - & + & + & + & + \\
Acid phosphatase & - & + & - & + & + & + & + \\
\hline
\end{tabular}

Identification system (Sasser, 1990). DNA G + C contents were determined according to the method of Mesbah $\mathrm{et}$ al. (1989) using a reversed-phase column (Supelcosil LC-18 S; Supelco). Both strains had $\mathrm{C}_{18: 1} \omega 7 c$ as the major fatty acid, which was in agreement with the fatty acid profiles of other Methylobacterium species (Supplementary Table S1, available in IJSEM Online). The DNA G $+\mathrm{C}$ content of strain $5317 \mathrm{~S}-33^{\mathrm{T}}$ was $68.0 \mathrm{~mol} \%$; that of strain $5413 \mathrm{~S}-11^{\mathrm{T}}$ was $73.2 \mathrm{~mol} \%$.

The 16S rRNA gene was amplified by using PCR with primers fD1 and rP2 (Weisburg et al., 1991) on colonies; the entire PCR fragment was sequenced directly (Hiraishi, 1992). The resultant 16S rRNA gene sequences were compared with available sequences from GenBank using the program BLAST (http://www.ncbi.nlm.nih.gov/blast/) to determine an approximate phylogenetic affiliation and gene sequences were aligned with those of closely related strains using the software CLUSTAL W (Thompson et al., 1994). Phylogenetic trees were constructed by the neighbour-joining method with the program package MEGA3 (Kumar et al., 2004). Bootstrap confidence values were obtained using 1000 resamplings. Phylogenetic trees were also constructed by using the maximum-parsimony method. DNA-DNA hybridization was carried out as described by Seldin \& Dubnau (1985). Probe labelling was conducted using a non-radioactive DIG High Prime DNA Labelling and Detection Starter kit II (Roche Molecular Biochemicals). Hybridized DNA was visualized using a DIG luminescent detection kit (Roche Molecular Biochemicals). The 16S rRNA gene sequence similarities between strain $5317 \mathrm{~S}-33^{\mathrm{T}}$ and the type strains of all recognized Methylobacterium species were in the range 93.6-97.9\%; its closest relative was Methylobacterium adhaesivum $\mathrm{AR} 27^{\mathrm{T}}$ ( $97.9 \%$ sequence similarity). Strain 5413S- $11^{\mathrm{T}}$ showed sequence similarity levels of 91.6-97.3\% with all type strains of the genus Methylobacterium. It revealed $>97 \%$ sequence similarity with Methylobacterium fujisawaense DSM $5686^{\mathrm{T}}$ (97.3\%), Methylobacterium oryzae $\mathrm{CBMB}^{\mathrm{T}} \mathrm{T}^{\mathrm{T}}(97.1 \%)$ and Methylobacterium radiotolerans JCM $2831^{\mathrm{T}}(97.0 \%)$. According to the neighbour-joining tree (Fig. 1), strain $5317 \mathrm{~S}-33^{\mathrm{T}}$ formed a compact cluster with M. adhaesivum AR2 $27^{\mathrm{T}}$ (99\% bootstrap support). Strain $5413 \mathrm{~S}-11^{\mathrm{T}}$ clustered with $M$. fujisawaense, $M$. oryzae, M. radiotolerans and Methylobacterium mesophilicum. The topologies of phylogenetic trees built using the maximum-parsimony algorithm also supported the notion that these isolates belong to the genus Methylobacterium (data not shown). Strain $5317 \mathrm{~S}-33^{\mathrm{T}}$ showed a level of DNA-DNA relatedness of $33 \%$ with M. adhaesivum DSM $17169^{\mathrm{T}}$. Strain $5413 \mathrm{~S}-11^{\mathrm{T}}$ showed low levels of DNA-DNA relatedness with $M$. fujisawaense DSM $5686^{\mathrm{T}}(34 \%), M$. oryzae CBMB20 $0^{\mathrm{T}}(28 \%)$ and $M$. radiotolerans DSM $1819^{\mathrm{T}}(35 \%)$. On the basis of this polyphasic taxonomic analysis, the names Methylobacterium iners sp. nov. and Methylobacterium aerolatum sp. nov. are proposed to accommodate these two novel strains. 


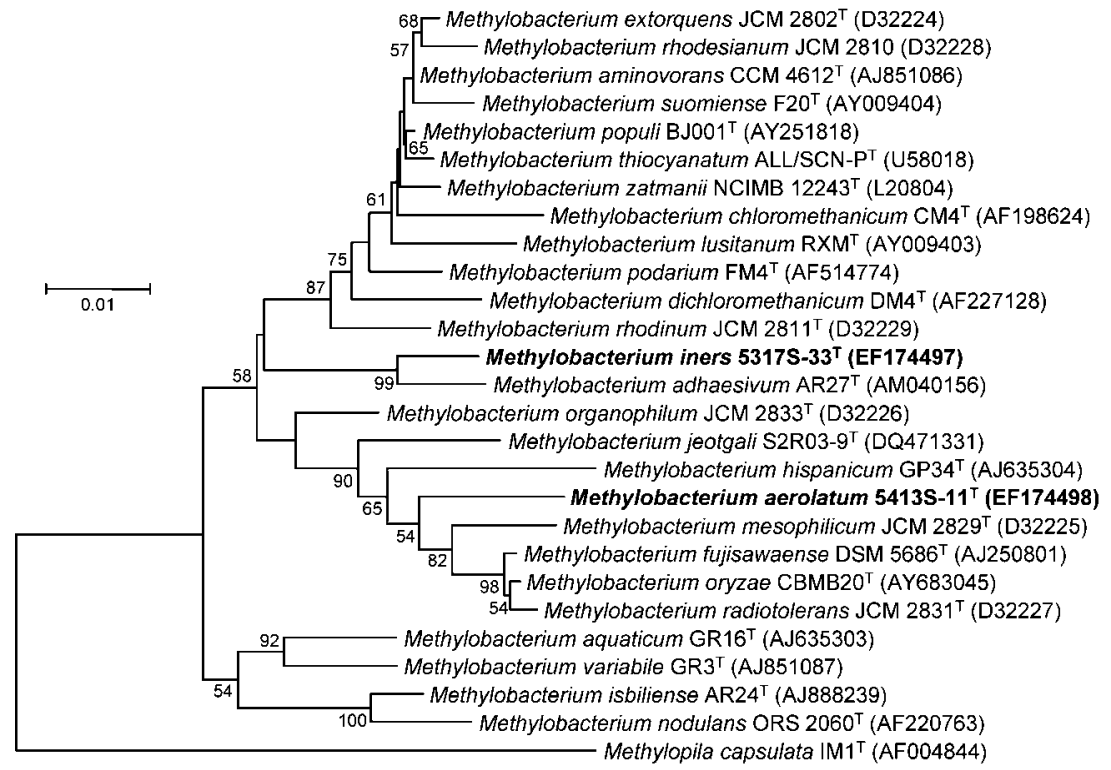

Fig. 1. Phylogenetic tree showing the relationship between strains $5317 \mathrm{~S}-33^{\top}$ and $5413 \mathrm{~S}-11^{\top}$ and related species. The tree was constructed by using the neighbour-joining method based on 16S rRNA gene sequences. Numbers at nodes indicate percentage bootstrap values from 1000 replicates. Bootstrap values greater than $50 \%$ are shown. Bar, 0.01 substitutions per nucleotide position.

\section{Description of Methylobacterium iners sp. nov.}

Methylobacterium iners (i'ners. L. neut. adj. iners inactive, lazy).

Cells are strictly aerobic, Gram-negative, motile and rodshaped $(1.0 \times 1.5-2.5 \mu \mathrm{m})$. Colonies are pink-coloured, circular and convex with entire margins. Produces oxidase and catalase. Growth is observed at $10-30{ }^{\circ} \mathrm{C}$ (optimum 25-28 ${ }^{\circ} \mathrm{C}$ ) and $\mathrm{pH}$ 6.0-8.0 (optimum 7.0). Cannot grow in the presence of $\mathrm{NaCl}$ concentrations of $2 \%$ or more. Hydrolyses starch, but does not hydrolyse casein, CMcellulose, DNA, hypoxanthine, Tween 80, tyrosine or xanthine. The following substrates produce positive results in Biolog GN2 plates: pyruvic acid methyl ester, acetic acid, formic acid, $\alpha$-hydroxybutyric acid, $\beta$-hydroxybutyric acid, $\alpha$-ketobutyric acid, DL-lactic acid, propionic acid, succinamic acid, L-asparagine, L-aspartic acid and L-glutamic acid. The major fatty acid is $\mathrm{C}_{18: 1} \omega 7 c$.

The type strain is $5317 \mathrm{~S}-33^{\mathrm{T}}$ (=KACC $11765^{\mathrm{T}}=\mathrm{DSM}$ $\left.19015^{\mathrm{T}}\right)$, isolated from an air sample in Suwon city, Republic of Korea. The DNA G $+C$ content of the type strain is $68.0 \mathrm{~mol} \%$.

\section{Methylobacterium aerolatum sp. nov.}

Methylobacterium aerolatum (ae.ro.la'tum. Gr. n. aer air; L. part. adj. latus carried; N.L. neut. part. adj. aerolatum airborne).

Cells are strictly aerobic, Gram-negative, motile and rodshaped $(1.0 \times 1.5-3.0 \mu \mathrm{m})$. Colonies are pink-coloured, circular and convex with entire margins. Produces oxidase and catalase. Growth is observed at $10-35{ }^{\circ} \mathrm{C}$ (optimum $28{ }^{\circ} \mathrm{C}$ ) and $\mathrm{pH}$ 5.0-9.0 (optimum 7.0). Cannot grow in the presence of $\mathrm{NaCl}$ concentrations of $2 \%$ or more.
Hydrolyses starch, hypoxanthine and xanthine, but does not hydrolyse casein, CM-cellulose, DNA, Tween 80 or tyrosine. The following substrates produce positive results in Biolog GN2 plates: pyruvic acid methyl ester, succinic acid monomethyl ester, formic acid, $\alpha$-hydroxybutyric acid, $\beta$-hydroxybutyric acid, $\gamma$-hydroxybutyric acid, $\alpha$-ketoglutaric acid, DL-lactic acid, succinic acid, bromosuccinic acid, succinamic acid and glycerol. The major fatty acid is $\mathrm{C}_{18: 1} \omega 7 c$.

The type strain is $5413 \mathrm{~S}-11^{\mathrm{T}}\left(=\mathrm{KACC} 11766^{\mathrm{T}}=\mathrm{DSM}\right.$ $\left.19013^{\mathrm{T}}\right)$, isolated from an air sample in Suwon city, Republic of Korea. The DNA G $+\mathrm{C}$ content of the type strain is $73.2 \mathrm{~mol} \%$.

\section{Acknowledgements}

This study was supported by the National Institute of Agricultural Biotechnology (NIAB grant no. 06-4-11-19-1), Rural Development Administration, Republic of Korea.

\section{References}

Corpe, W. A. \& Rheem, S. (1989). Ecology of the methylotrophic bacteria on living leaf surfaces. FEMS Microbiol Ecol 62, 243-249.

Green, P. N. (1992). The genus Methylobacterium. In The Prokaryotes, 2nd edn, pp. 2342-2349. Edited by A. Balows, H. G. Trüper, M. Dworkin, W. Harder \& K. H. Schleifer. New York: Springer.

Hiraishi, A. (1992). Direct automated sequencing of $16 \mathrm{~S}$ rDNA amplified by polymerase chain reaction from bacterial cultures without DNA purification. Lett Appl Microbiol 15, 210-213.

Kumar, S., Tamura, K. \& Nei, M. (2004). MEGA3: integrated software for molecular evolutionary genetics analysis and sequence alignment. Brief Bioinform 5, 150-163.

Lidstrom, M. E. \& Chistoserdova, L. (2002). Plants in the pink: cytokinin production by Methylobacterium. J Bacteriol 184, 1818. 
Mesbah, M., Premachandran, U. \& Whitman, W. B. (1989). Precise measurement of the $\mathrm{G}+\mathrm{C}$ content of deoxyribonucleic acid by highperformance liquid chromatography. Int J Syst Bacteriol 39, 159-167.

Patt, T. E., Cole, G. C. \& Hanson, R. S. (1976). Methylobacterium, a new genus of facultatively methylotrophic bacteria. Int J Syst Bacteriol 26, 226-229.

Sasser, M. (1990). Identification of bacteria by gas chromatography of cellular fatty acids, MIDI Technical Note 101. Newark, DE: MIDI.

Seldin, L. \& Dubnau, D. (1985). Deoxyribonucleic acid homology among Bacillus polymyxa, Bacillus macerans, Bacillus azotofixans, and other nitrogen-fixing Bacillus strains. Int J Syst Bacteriol 35, 151-154.
Smibert, R. M. \& Krieg, N. R. (1994). Phenotypic characterization. In Methods for General and Molecular Bacteriology, pp. 607-654. Edited by P. Gerhardt, R. G. E. Murray, W. A. Wood \& N. R. Krieg. Washington, DC: American Society for Microbiology.

Thompson, J. D., Higgins, D. G. \& Gibson, T. J. (1994). CLUSTAL W: improving the sensitivity of progressive multiple sequence alignment through sequence weighting, position-specific gap penalties and weight matrix choice. Nucleic Acids Res 22, 4673-4680.

Weisburg, W. G., Barns, S. M., Pelletier, D. A. \& Lane, D. J. (1991). $16 \mathrm{~S}$ ribosomal DNA amplification for phylogenetic study. J Bacteriol 173, 697-703. 